\title{
Cell-mediated immune reactions against $B$ cells and defect of suppressor cell activity in Type 1 (insulin-dependent) diabetes mellitus
}

\author{
D. Lohmann, J. Krug, E. F. Lampeter, B. Bierwolf and H.-J. Verlohren \\ City Hospital Leipzig, Leipzig, GDR
}

Summary. A cytotoxic effect of peripheral blood mononuclear cells from 22 out of 23 newly diagnosed Type 1 (insulin-dependent) diabetic patients against $B$ cells of isolated rat islets was demonstrated. The addition of peripheral blood mononuclear cells from healthy subjects reduced the cytotoxic effect in 9 out of 10 patients. The addition of peripheral blood mononuclear cells from other diabetic patients was without significant effect in 14 out of 16 cases. The results indicate functional abnormalities of peripheral blood mononuclear cells in newly diagnosed Type 1 diabetes. Beside cytotoxic effects against $B$ cells, a defect in the suppressor function seems to exist. The activation of T-lymphocytes might be a consequence of such a defect.

Key words: Type 1 diabetes, cell-mediated anti B-cell cytotoxicity, defect of suppressor cell function.
It is commonly supposed that various cell-mediated immunoprocesses are involved in the destruction of $B$ cells of the pancreas in Type 1 (insulin-dependent) diabetes mellitus. Morphologically an infiltration of the islets of Langerhans in juvenile diabetic patients who had died shortly after diagnosis has been known for many years $[1,2]$.

During the last few years differences in the percentage of T-lymphocyte subsets were found in this disorder [3-7]. These are only nonspecific findings, and the participation of these cells in inducing damage of the B cells has not been established. Direct functional effects of lymphocytes from Type 1 diabetic patients have been demonstrated by the leucocyte migration inhibition test [8] and by suppression of the stimulated insulin secretion from isolated mouse islet cells $[9,10]$. Charles et al. [11] reported direct cytotoxicity on isolated islets by lymphocytes in a chromium release assay.

In previous studies, we observed morphological evidence of lyses of B cells in isolated rat and human islets by $\mathrm{CD} 8^{+}$lymphocytes from newly diagnosed Type 1 diabetic patients $[12,13]$. To date, most authors have presumed that the cause of the activation of the T-lymphocytes in Type 1 diabetes is due to an immune stimulation by the target cell. Only few reports have discussed the possibility that a defect in the suppressor cell function could be responsible for the activation of the cytotoxic T-cells [14-17]. We have attempted to contribute to an understanding of this problem. by studying cyto- toxic and suppressor cell functions of peripheral blood mononuclear cells (PBMC) from newly diagnosed Type 1 diabetic patients.

\section{Subjects and methods}

\section{Subjects}

Twenty-three patients were investigated within 4 weeks after hospitalisation due to overt hyperglycaemia. All patients needed insulin from the time of diagnosis and also in the further course of the disease. The patients were characterized by a markedly reduced C-peptide level and were typed for their HLA-DR phenotypes. Fifteen normoglycaemic subjects without family history of diabetes served as control probands (Table 1). The diabetic patients were free of clinical signs of other autoimmune diseases or endocrinopathies. The radioreceptor assay for thyroid stimulating hormone receptor antibodies was negasive in all cases (TRAK-Assay, Henning, Berlin, FRG).

\section{Preparation of islets}

Islets were isolated from the pancreas of 10 to 12-day-old Wistar rats by collagenase digestion [18]. The islets were first incubated for $2 \mathrm{~h}$ at $37^{\circ} \mathrm{C}$ in a humified atmosphere of $5 \% \mathrm{CO}_{2} / 95 \% \mathrm{O}_{2}$ in Eagle Basal Medium (pH 7.4) supplemented with $1.0 \mathrm{~g} / 1$ bovine serum albumin, $2 \mathrm{mmol} / \mathrm{l} \mathrm{L}$-glutamine, $20 \mathrm{mmol} / 1$ Hepes, $5.0 \mathrm{~g} / 1$ lactalbumin-hydrolysate, $5.5 \mathrm{mmol} / 1$ glucose, $2 \times 10^{5} \mathrm{U} / 1$ penicillin $\mathrm{G}$ and $200 \mathrm{mg} / 1$ streptomycin (=EBM).

\section{Isolation of PBMC}

PBMC were prepared from $20 \mathrm{ml}$ heparinized venous blood (preservative-free heparin, Gedeon Richter, Budapest, Hungary) by the Fi- 
Table 1. Clinical data and results of the insulin release assay of the Type 1 diabetic patients and the control subjects. Insulin content (ng/islet per $20 \mathrm{~h}$ ) in the culture medium after 20 - $\mathrm{h}$ incubation of rat islets in incubation medium (EBM) $=$ control or EBM + peripheral blood mononuclear cells of newly onset Type 1 diabetic patients $(n=23$; upper part) and of control subjects (HP $1-15$; lower part). Diabetic patients $1-10$ tested in combination with peripheral blood mononuclear cells of healthy probands

\begin{tabular}{|c|c|c|c|c|c|c|c|}
\hline Patient & Sex & $\begin{array}{l}\text { Age at } \\
\text { onset } \\
\text { (years) }\end{array}$ & $\begin{array}{l}\text { HLA } \\
\text { (DR) }\end{array}$ & $\begin{array}{l}\text { EBM } \\
\text { (ng insulin/20h) }\end{array}$ & $\begin{array}{l}\text { EBM and } \\
\text { peripheral blood } \\
\text { mononuclear cells } \\
\text { (ng insulin } / 20 \mathrm{~h} \text { ) }\end{array}$ & $\begin{array}{l}\% \text { of } \\
\text { EBM }\end{array}$ & $\begin{array}{l}\text { Tested with } \\
\text { healthy control } \\
\text { (n) }\end{array}$ \\
\hline \multicolumn{8}{|c|}{ Type 1 diabetic patients } \\
\hline 1 & $\mathrm{~m}$ & 20 & $3 / 4$ & 9.7 & 29.6 & 306 & HP 1 \\
\hline 2 & $\mathrm{f}$ & 9 & $1 / 7$ & 14.6 & 27.8 & 191 & HP 2 \\
\hline 5 & f & 16 & $3 / 4$ & 4.1 & 8.9 & 218 & HP 5 \\
\hline 6 & $\mathrm{~m}$ & 25 & $2 / 4$ & 10.3 & 22.5 & 219 & HP 6 \\
\hline 7 & $\mathrm{f}$ & 39 & 4 & 16.5 & 34.9 & 211 & HP 7 \\
\hline 8 & f & 14 & $3 / 4$ & 17.2 & 25.5 & 148 & HP 8 \\
\hline 9 & $\mathrm{f}$ & 15 & $2 / 3$ & 9.6 & 13.6 & 142 & $\mathrm{HP} \quad 9 / 10$ \\
\hline 10 & $\mathrm{~m}$ & 20 & $4 / 5$ & 10.2 & 30.3 & 297 & $\mathrm{HP} 11 / 12$ \\
\hline 15 & $\mathrm{~m}$ & 22 & $3 / 4$ & 15.0 & 22.1 & 147 & - \\
\hline 16 & f & 28 & 4 & 12.2 & 11.2 & 92 & - \\
\hline 17 & $\mathrm{f}$ & 31 & $3 / 4$ & 7.1 & 12.1 & 170 & - \\
\hline 18 & $\mathrm{~m}$ & 36 & 4 & 11.4 & 18.4 & 162 & - \\
\hline 19 & $\mathrm{~m}$ & 26 & 4 & 6.7 & 11.2 & 167 & - \\
\hline 20 & $\mathrm{~m}$ & 15 & 4 & 9.2 & 24.2 & 263 & - \\
\hline 21 & $\mathrm{~m}$ & 19 & 4 & 7.1 & 16.3 & 230 & - \\
\hline 22 & $\mathrm{~m}$ & 12 & 4 & 9.8 & 15.9 & 162 & - \\
\hline 23 & $\mathrm{f}$ & 13 & 4 & 12.8 & 18.9 & 148 & - \\
\hline \multicolumn{8}{|l|}{ Mean } \\
\hline SD & & & & 3.5 & 7.3 & 55.6 & \\
\hline
\end{tabular}

\section{Control}

subjects

\begin{tabular}{|c|c|c|c|c|c|c|}
\hline HP 1 & $\mathrm{~m}$ & 32 & 7 & 9.7 & 11.6 & 120 \\
\hline HP 2 & $\mathrm{~m}$ & 27 & $2 / 4$ & 14.5 & 12.4 & 85 \\
\hline HP 3 & $\mathrm{~m}$ & 40 & 7 & 10.5 & 6.4 & 63 \\
\hline HP 4 & $\mathrm{~m}$ & 44 & $3 / w 6$ & 8.8 & 10.4 & 118 \\
\hline HP 5 & f & 21 & $5 / w 6$ & 4.1 & 4.8 & 118 \\
\hline HP 6 & $f$ & 24 & $3 / 4$ & 10.3 & 12.3 & 119 \\
\hline HP 7 & $\mathrm{f}$ & 29 & w $6 / 7$ & 16.5 & 20.3 & 123 \\
\hline HP 8 & $\mathrm{~m}$ & 33 & $1 / 4$ & 17.2 & 17.1 & 99 \\
\hline HP 9 & $\mathrm{~m}$ & 42 & $1 / 2$ & 9.6 & 8.3 & 86 \\
\hline HP 10 & $\mathrm{f}$ & 37 & 3 & 9.6 & 7.2 & 75 \\
\hline HP 11 & $\mathrm{~m}$ & 47 & $4 / 7$ & 10.2 & 12.9 & 126 \\
\hline HP 12 & f & 49 & $4 / 5$ & 10.2 & 12.3 & 121 \\
\hline HP 13 & f & 19 & 3 & 11.5 & 13.2 & 115 \\
\hline HP 14 & $\mathrm{f}$ & 22 & 4 & 8.2 & 9.9 & 108 \\
\hline HP 15 & $\mathrm{~m}$ & 29 & 4 & 9.3 & 9.5 & 103 \\
\hline $\begin{array}{l}\text { Uean } \\
\text { NP 1-15) }\end{array}$ & & 33.0 & & & & \\
\hline D & & 30.0 & & $\begin{array}{r}10.1 \\
3.3\end{array}$ & $\begin{array}{r}11.2 \\
4.0\end{array}$ & 19.6 \\
\hline EM & & & & 0.8 & 1.0 & 5.0 \\
\hline
\end{tabular}

+ No examination

coll Hypaque technique [19], washed three times and adjusted to a final concentration of $5 \times 10^{6} \mathrm{cells} / \mathrm{ml}$. The PBMC were preincubated in EBM for $2 \mathrm{~h}$. Viability was tested by the trypan exclusion test. Only preparations with a viability higher than $90 \%$ were used. PBMC prepared and incubated in EBM as described above did not release any insulin immunoreactivity into the medium.

\section{Insulin release assay}

Ten islets were incubated either in EBM alone (control) or together with $0.2 \mathrm{ml}$ PBMC suspension in glass dishes for $20 \mathrm{~h}$ at $37^{\circ} \mathrm{C}$ with $5 \%$ $\mathrm{CO}_{2} / 95 \% \mathrm{O}_{2}$. After the incubation, the insulin content in the medium was determined by the alcohol precipitation method using a rat insu- 
Table 2. Insulin release during incubation of rat islets with peripheral blood mononuclear cells of Type 1 diabetic patients and following insulin secretion after stimulation by $10 \mathrm{mmol} / \mathrm{l}$ arginine

\begin{tabular}{lll}
\hline Patient & $\begin{array}{l}\text { PBMC effect on basal in- } \\
\text { sulin release }\end{array}$ & $\begin{array}{l}\text { PBMC effect on argi- } \\
\text { nine-stimulated insulin } \\
\text { secretion }^{\mathrm{a}}\end{array}$ \\
\hline 1 & 306 & 54 \\
2 & 191 & 47 \\
3 & 245 & 56 \\
4 & 198 & 56 \\
5 & 218 & 42 \\
6 & 219 & 60 \\
7 & 211 & 61 \\
8 & 148 & 66 \\
10 & 297 & 43 \\
13 & 198 & 70 \\
14 & 254 & 84 \\
17 & 170 & 47 \\
20 & 263 & 91 \\
Mean & 224.5 & 59.1 \\
SD & 46.8 & 15.5 \\
Control group & $p<0.001$ & $p<0.001$ \\
$\quad(n=11)$ & & \\
Mean & 107.2 & 94.1 \\
SD & 20.1 & 17.8 \\
\hline
\end{tabular}

a Expressed in percent of control values

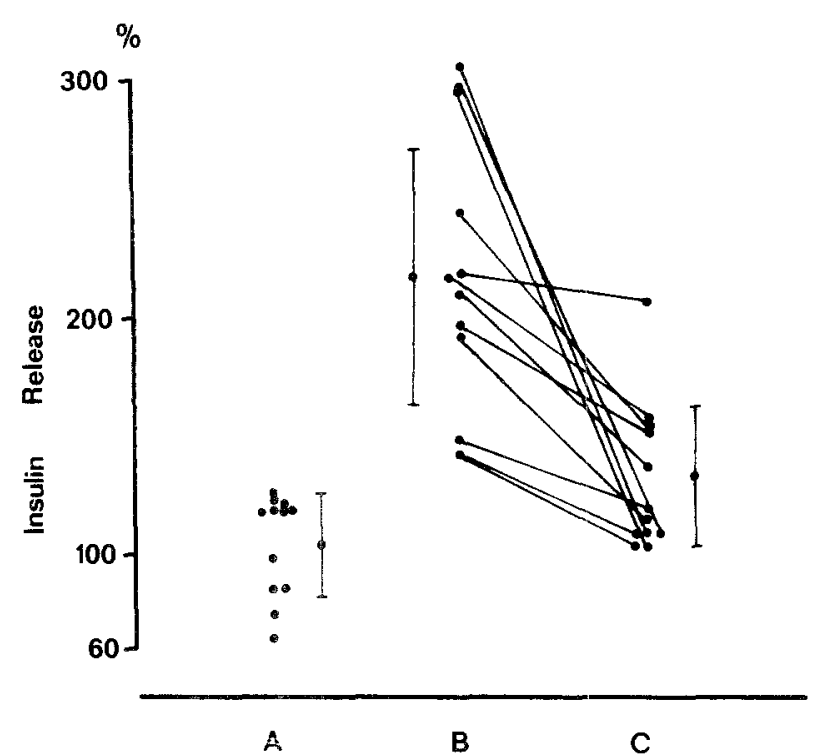

Fig. 1. Insulin release from rat islets during incubation with peripheral blood mononuclear cells from healthy subjects (A), and from Type 1 diabetic patients without (B) and with (C) addition of PBMC from healthy probands - $(1: 4)$ (control in incubation medium alone $=100 \%)(p<0.001)$

lin standard (Novo Research Institute. Copenhagen, Denmark, Batch-No. 810611) [20]. The relative effect of the PBMC was calculated as percentage of insulin released in the appropriate control experiment, i.e. islets incubated in medium alone.

\section{Measurement of insulin secretion capacity}

After the 20-h incubation period, the islets were washed, preincubated in EBM for $1 \mathrm{~h}$ and then stimulated with $10 \mathrm{mmol} / 1$ arginine for $3 \mathrm{~h}$.
The insulin secretion into the medium was then measured. The secretion capacity was calculated as per cent of the control value, i. e. insulin secretion during incubation for $20 \mathrm{~h}$ in EBM alone.

\section{Test of suppressor cell function}

In order to evaluate if the insulin release caused by PBMC of diabetic patients could be modulated by PBMC of healthy subjects, in 10 cases $1 \times 10^{6} \quad$ PBMC from diabetic patients were mixed with $2.5 \times 10^{5}$ PBMC (4:1 ratio) from control subjects (and in a ratio of $19: 1$ in 6 cases). The mixture was incubated in EBM for $1 \mathrm{~h}$ and then used in the insulin release assay as described above. The individual combinations and HLA-DR phenotypes can be taken from Table 1. To exclude nonspecific effects of the PBMC mixture, PBMC from diabetic patients with positive cytotoxic reactions were applied.

All tests were performed in duplicate. The mean deviation from the mean value was lower than $10 \%$.

\section{Statistical analysis}

All results are presented as mean $\pm S D$. The significance of differences was evaluated by the Wilcoxon U test, Mann-Whitney test (control subjects - diabetic patients) or the Wilcoxon matched pairs signed-rank test (experiments with mixed lymphocytes).

\section{Results}

In 22 of the 23 Type 1 diabetic patients, an increased insulin release from rat islets after incubation with isolated PBMC could be demonstrated (Table 1). The nonstimulated insulin release in the group of PBMC preparations from the diabetic patients amounted to $200 \%$ expressed relative to the EBM medium alone (being 100\%). In the subsequent insulin secretion test the secretion capacity was significantly reduced $(p<0.001)$ if the islets had been incubated with PBMC from diabetic patients (Table 2). In the tests with PBMC from control subjects no significant effect could be seen either in the nonstimulated insulin release (Table 1) or in the subsequent stimulation period (Table 2). The individual HLA types did not reveal a predominance of any HLA-DR type which enhanced insulin release (Table 1 ). Other clinical parameters also did not correlate with measures of insulin secretion.

The addition of PBMC from healthy subjects abolished the increased insulin release caused by PBMC from Type 1 diabetic patients in 9 out of 10 cases (Fig.1). The reduction amounted to more than $50 \%$ $(p<0.001)$. Nearly the same effect resulted by addition of PBMC from control subjects in the ratio of $1: 19$ in 5 out of 6 cases (Fig. 2). The PBMC addition in a ratio of 1:200 was without any significant effect ( 3 cases).

The addition of PBMC from another diabetic patient (with positive cytotoxic reaction) did not result in a significant $(>20 \%)$ reduction in 14 out of 16 cases (Fig. 3).

The HLA pattern of the diabetic patients showed a typically higher incidence of DR 3 and DR 4. The suppressor effect of control PBMC in the insulin release assay seems uncorrelated to the constellation of the HLA 


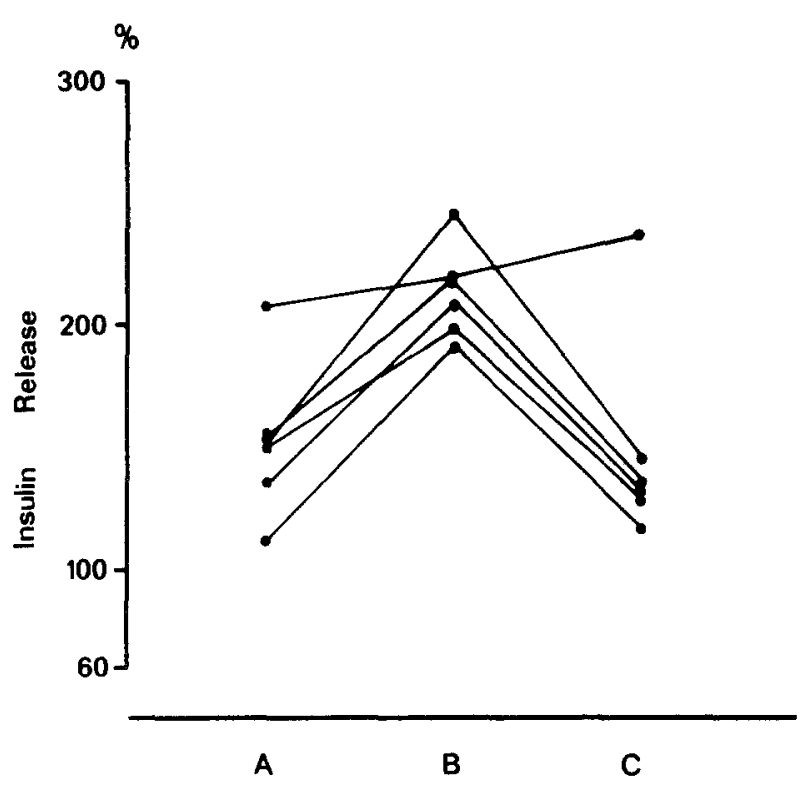

Fig. 2. Insulin release from rat islets during incubation with peripheral blood mononuclear cells from Type 1 diabetic patients with addition of PBMC from healthy probands 1:4 (A), without addition of PBMC (B) and with addition of PBMC 1: 19 (C) (control in incubation medium alone $=100 \%$ )

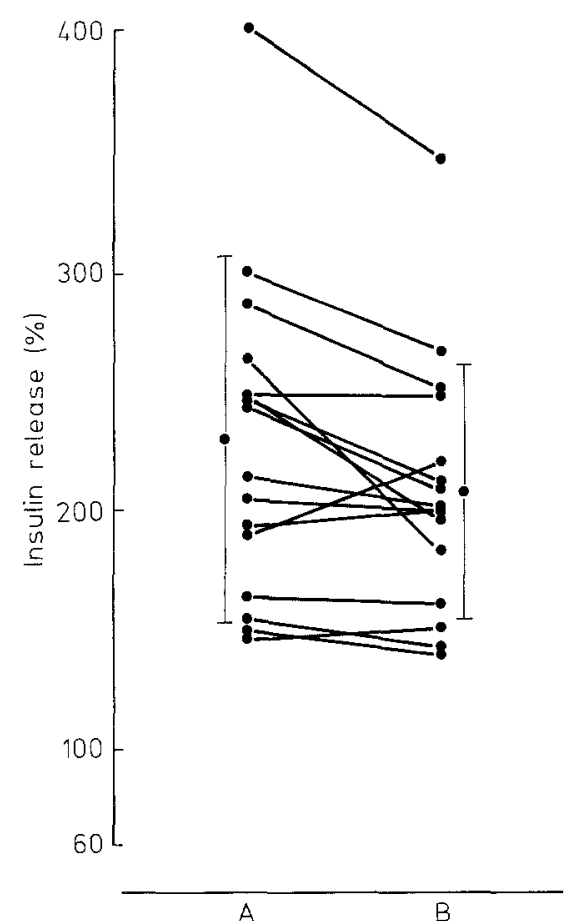

Fig.3. Insulin release from rat islets during incubation with peripheral blood mononuclear cells from Type 1 diabetic patients without (A) and with (B) addition of $\mathrm{PBMC}$ from other diabetic patients (control in incubation medium alone $=100 \%$ )

types, as can be seen by the combinations from Table 1 . The HLA types were not matched in all our experiments.

\section{Discussion}

Our results demonstrate that PBMC from newly diagnosed Type 1 diabetic patients cause an increased non- stimulated insulin release from B cells of isolated rat islets. This is in agreement with the results of Charles et al. [11], who used a chromium-release test. The reduced insulin secretion capacity after the incubation with PBMC from diabetic patients also supports the results of Boitard et al. [9], who found decreased insulin secretion after the incubation in mouse islet cells. Boitard et al. [10] could identify this effect as a T-cell phenomenon. By morphological methods we demonstrated that $B$ cells can be attacked by lymphocytes $[12,13]$ with a consecutive B-cell necrosis. The missing effect of PBMC from healthy subjects contradicts the assumption that this cytotoxic effect is a result of a xenogenic system.

The addition of PBMC from healthy probands significantly reduces the cytotoxic effect. These results cannot be explained by nonspecific interactions between the PBMC stemming from different subjects, since the addition of PBMC from healthy individuals and from newly diagnosed diabetic patients was at variance.

In both groups the individual mixtures (diabetic plus control PBMC and diabetic plus diabetic PBMC respectively) are not HLA-matched. Therefore, the differences in suppression cannot be simply the result of a PBMC interaction from individuals with more or less compatible HLA types. The incubation time of $20 \mathrm{~h}$ also seems too short to produce the effects of a mixed lymphocyte culture. Similar results were obtained by Topliss et al. [17] using the leucocyte migration test.

Taking these observation together with our preliminary morphological findings $[12,13]$ and the results of Boitard [10] and Charles [11], we suggest that cytotoxic effects of activated T-lymphocytes can induce the damage of $B$ cells in Type 1 diabetes. The activation of these cells could be the consequence of an imbalance in the immunoregularity system, in which a defect of activities of suppressor cells plays a primary role.

\section{References}

1. Le Compte PM (1958) "Insulitis" in early juvenile diabetes mellitus. Pathology 66: 450-457

2. Gepts W (1965) Pathologic anatomy of the pancreas in juvenile diabetes mellitus. Diabetes 14:616-633

3. Horita M, Suzuki H, Onodera T, Ginsberg-Fellner E, Fauci AS, Notkins AL (1982) Abnormalities of immunregulatory subsets in patients with insulin-dependent diabetes mellitus. J Immunol 126: 1426-1429

4. Buschard K, Röpke C, Madsbad S, Mehlsen J, Rygaard J (1983) T lymphocyte subsets in patients with newly diagnozed Type 1 (insulin dependent) diabetes mellitus: a prospective study. Diabetologia $25: 247-251$

5. Buschard K, Röpke C, Madsbad S, Mehlsen J, Srensen TB, Rygaard $\mathbf{J}$ (1983) Alterations of peripheral T lymphocyte subpopulations in patients with insulin-dependent (Type 1) diabetes mellitus. J Clin Lab Immunol 10: 127-131

6. Pozzilli P, Zuccarini O, Iavicoli M, Andreani D, Sensi M, Spencer KM, Bottazzo GF, Beverly PCL, Kyner JL, Cudworth AG (1983) 
Monoclonal antibodies defined abnormalities of T lymphocytes in Type I (insulin-dependent) diabetes. Diabetes 32:91-94

7. Mascart-Lemone F, Delespesse G, Dorchy H, Lemiere B, Servais $G$ (1982) Characterization of immunoregulatory $T$ lymphocytes in insulin-dependent diabetic children by means of monoclonal antibodies. Clin Exp Immunol 47: 296-300

8. Nerup J, Andersen OO, Bendixen G, Egeverg J, Poulsen JE (1971) Antipancreatic cellular hypersensitivity in diabetes mellitus. Diabetes 20:424-427

9. Boitard C, Debray-Sachs M, Pouplard A, Assan R, Hamburger J (1981) Lymphocytes from diabetics suppress insulin release in vitro. Diabetologia 21:41-46

10. Boitard C, Chatenond LM, Debray-Sachs M (1982) In vitro inhibition of pancreatic $b$ cell function by lymphocytes from diabetics with associated autoimmune diseases: a T cell phenomenon. J Immunol 129: 2529-2531

11. Charles AM, Suzuki M, Waldeck N, Dodson LE, Slater L, Ong K, Kershnar A, Buckinham B, Golden M (1983) Immune islet killing mechanisms associated with insulin-dependent diabetes: in vitro expression of cellular and antibody-mediated islet cell cytotoxicity in humans. J Immunol 130: 1189-1194

12. Lampeter EF, Bierwolf B, Lohmann D, Wohlrab F, Cossel L (1984) Simultaneous biochemical and morphological investigations on the effect of leukocytes from type I diabetics on isolated rat islets. Biomed Biochem Acta 43: 647-656

13. Lohmann D, Lampeter E, Bierwolf B, Cossel L (1985) Morphological studies on cell mediated beta cell damage. In: IDDM. XII Congress of IDF, Diabetes Research and Clinical Practice, Supplement 1. Elsevier (Abstract 887)
14. Horowitz SD, Borcheching W, Bargman GJ (1977) Suppressor T cell function in diabetes mellitus. Lancet 2: 1291

15. Buschard K, Madsbad S, Rygaard J (1980) Depressed suppressor cell activity in patients with newly diagnosed insulin-dependent diabetes mellitus. J Clin Immunol 41: 25-32

16. Lederman MM, Ellner JJ, Rodman HM (1981) Defective supressor cell generation in juvenile onset diabetes. J Immunol 127 : 2051-2055

17. Topliss, D, How J, Lewis M, Row V, Volpé R (1983) Evidence of cell-mediated immunity and specific suppressor $\mathrm{T}$ lymphocyte dysfunction in Graves' Disease and diabetes mellitus. J Clin Endocrinol 57: 700-705

18. Moskalewski S (1965) Isolation and culture of the islets of Langerhans of the Guinea pig. Gen Comp Endocrinol 5: 342-353

19. Byum A (1968) Separation of leucocytes from blood and bone marrow. Scand J Lab Invest 21: 28

20. Ziegler M, Michael R, Stein HE, Klatt D (1974) Radioimmunoassay von Pankreasglukagon isolierter Langerhans'scher Ratteninseln nach dem Prinzip der Rücktitration. Radiobiol Radiother 15: $79-84$

Received: 9 January 1986

and in revised form: 30 May 1986

Professor Dr. D. Lohmann

City Hospital Leipzig

Friesenstraße 8

DDR-7033 Leipzig

GDR 